\title{
Prediction Method for Large Diatom Appearance with Meteorological Data and MODIS Derived Turbidity and Chlorophyll-A in Ariake Bay Area in Japan
}

\author{
Kohei Arai ${ }^{1}$ \\ 1 Graduate School of Science and Engineering \\ Saga University \\ Saga City, Japan
}

\begin{abstract}
Prediction method for large diatom appearance in winter with meteorological data and MODIS derived turbidity and chlorophyll-a in Ariake Bay Area in Japan is proposed. Mechanism for large diatom appearance in winter is discussed with the influencing factors, meteorological condition and in-situ data of turbidity, chlorophyll-a data with the measuring instruments equipped at the Saga University own Tower in the Ariake Bay area. Particularly, the method for estimation of turbidity is still under discussion. Therefore, the algorithm for estimation of turbidity with MODIS data is proposed here. Through experiments, it is found that the proposed prediction method for large diatom appearance is validated with the meteorological data and MODIS derived turbidity as well as chlorophyll-a data estimated for the winter (from January to March) in 2012 and 2015.
\end{abstract}

Keywords-chlorophyl-a concentration; red tide; diatom; MODIS; satellite remote sensing

\section{INTRODUCTION}

The Ariake Sea is the largest productive area of Nori (Porphyra yezoensis ${ }^{1}$ ) in Japan. In winters in 2012, 2013, 2014 and 2015, as well as 2016, a massive diatom bloom appeared in the Ariake Bay, Japan [1]. In case of above red tides, bloom causative was Rhizosolenia imbricate ${ }^{2}$ and Eucampia zodiacus ${ }^{3}$. This bloom has been occurred several coastal areas in Japan and is well reported by Nishikawa et al. for Harima-nada sea areas [2]-[10]. Diatom blooms have recurrently appeared from late autumn to early spring in the coastal waters of western Japan, such as the Ariake Bay [11] and the Seto Inland Sea [12], where large scale "Nori" aquaculture occurs. Diatom blooms have caused the exhaustion of nutrients in the water column during the "Nori" harvest season. The resultant lack of nutrients has suppressed the growth of "Nori" and lowered the quality of "Nori" products due to bleaching with the damage of the order of billions of Japanese yen [3].

The chlorophyll-a concentration algorithm developed for MODIS $^{4}$ has been validated [13]. The algorithm is applied to

\footnotetext{
${ }^{1}$ http://en.wikipedia.org/wiki/Porphyra

${ }^{2}$ https://microbewiki.kenyon.edu/index.php/Rhizosolenia

${ }^{3} \mathrm{http}: / /$ www.eos.ubc.ca/research/phytoplankton/diatoms/centric/eucampia/e_z o

diacus.html

${ }^{4}$ http://modis.gsfc.nasa.gov/
}

MODIS data for a trend analysis of chlorophyll-a distribution in the Ariake Bay in winter during from 2010 to 2015 is made [13]. Also, locality of red tide appearance in Ariake Sea (Ariake Bay), Isahaya Bay and Kumamoto offshore is clarified by using MODIS data derived chlorophyll-a concentration [14]. On the other hand, red tide appearance (location, red tide species, the number of cells in unit water volume by using microscopy) are measured from the research vessel of the Saga Prefectural Fishery Promotion Center: SPFPC by once 10 days. The location and size of the red tide appearance together with the red tide source would be clarified by using SPFPC data. Match-up data of MODIS derived chlorophyll-a concentration is used for investigation of relations between MODIS data and truth data of the red tide appearance. Through time series data analysis of MODIS derived chlorophyll-a concentration, one of the possible causes of diatom appearance is clarified with the evidence of Research Bessel observations. Time series data analysis is made for large size diatom appearance events and meteorological data as well as MODIS derived Photosynthetically Available Radiance: PAR ${ }^{5}$, Chlorophyll-a concentration. The results from the time series analysis say that large size of diatoms appear after a long period time of relatively small size of red tide appearance [15]. Also, it depends on the weather conditions and tidal effect as well as water current in the bay area. Also, a relation between large sized diatom appearance and meteorological data in Ariake Bay Area in Japan in the winter in 2016 is discussed [16].

In this paper, a prediction method for large diatom appearance in winter with meteorological data and MODIS derived turbidity and chlorophyll-a in Ariake Bay Area in Japan is proposed. Although the mechanism for large diatom appearance in winter is discussed in the previous papers [1][12], there is no paper which deals with a prediction method for diatom appearance so far. This paper proposes a prediction method through discussions of mechanism for diatom appearance with the influencing factors, meteorological condition and in-situ data of turbidity, chlorophyll-a data with the measuring instruments equipped at the Saga University own Tower $^{6}$ in the Ariake Bay area. There is no reliable

\footnotetext{
${ }^{5}$ https://modis.gsfc.nasa.gov/data/dataprod/dataproducts.php?MOD_NUMBE $\mathrm{R}=22$

${ }^{6}$ http://www.ilt.saga-u.ac.jp/aripro/tower/index.html
} 
estimation method for turbidity with MODIS data [17]. Therefore, the algorithm for estimation of turbidity with MODIS data is also proposed here.

In the next section, the proposed prediction method and procedure is described followed by experimental data and prediction results. Then conclusion is described with some discussions.

\section{PROPOSED METHOD AND EXPERIMENTS}

\section{A. Intensive Study Areas}

Fig.1 shows the intensive study areas of Ariake Bay, Kyushu, Japan.

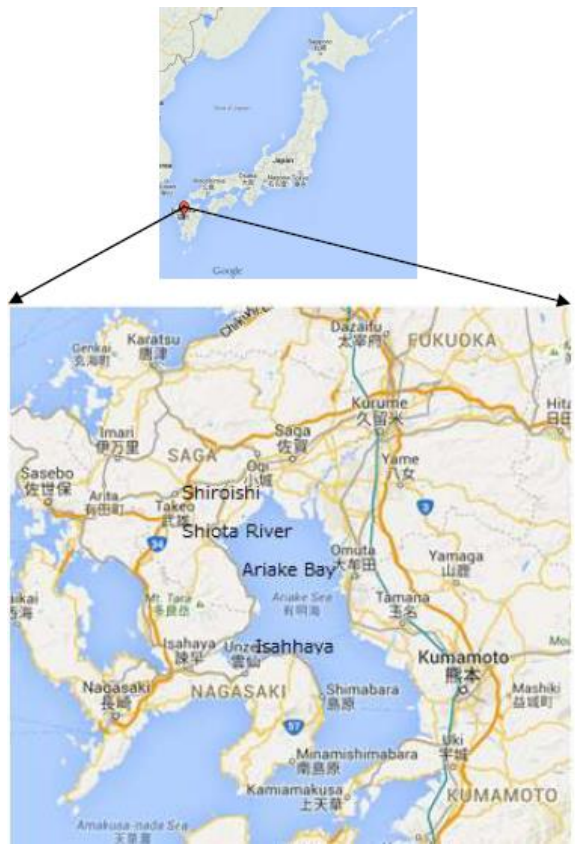

Fig. 1. Intensive study areas

Ariake Bay is a portion of Ariake Sea of which the width is around $20 \mathrm{~km}$ (in direction of east to west) and the length is approximately $100 \mathrm{~km}$ (in direction of north to south). It is almost closed sea area because the mouth of Ariake Sea is quite narrow. Sea water exchanges are, therefore, very small.

\section{B. Mechanism for Diatom Appearance in Winter}

Examples of the MODIS derived chlorophyll-a concentration which are acquired in the late of December 2011 to the begging of April 2012 are shown in Fig.2. The MODIS clear scenes of data acquisition dates for the period from December 2011 to April 2012 are followings,

(1) $2011 / 12 / 5,13,19,25,27,30$

(2) $2012 / 1 / 7,12,17,21,23,26,30,31$

(3) $2012 / 2 / 4,11,12,20,24,27$

(4) $2012 / 3 / 12,14,21,25,26,27,29$

(5) $2012 / 4 / 1,7,12,15,17,22,26,27,28$

The examples of the chlorophyll-concentrations for 2011/12/30, 2012/2/12, 2012/4/1 are just example of sparsely distributed chlorophyll-a concentration on December 30 in 2011 and examples of densely distributed chlorophyll-a concentration on February 12 in 2012 and April 12012.

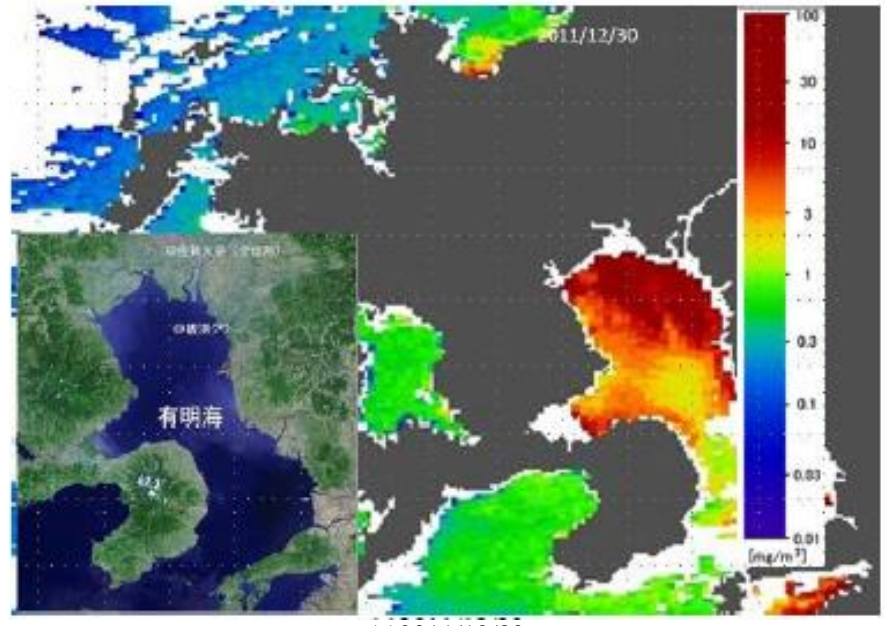

(a) $2011 / 12 / 30$

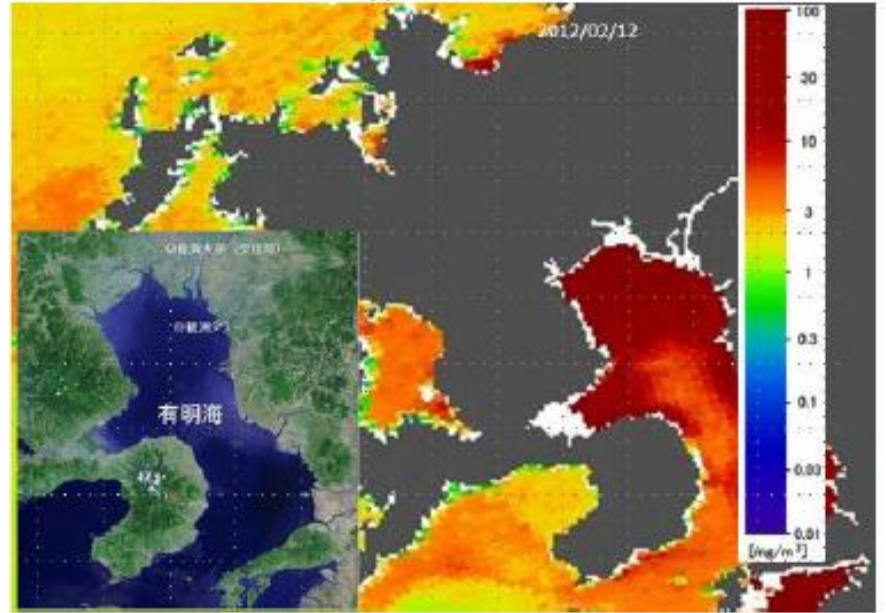

(b) $2012 / 2 / 12$

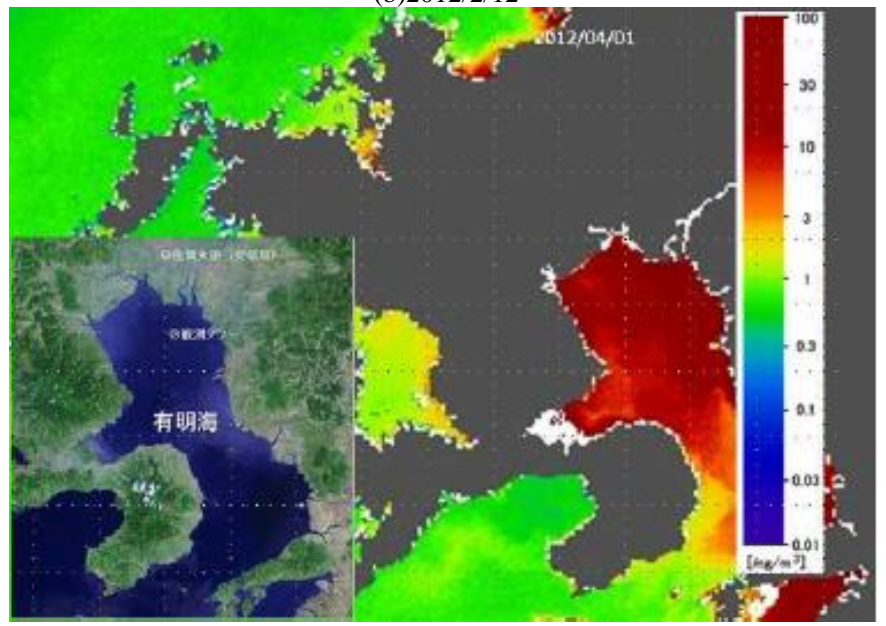

(c)2012/4/1

Fig. 2. MODIS derived chlorophyll-a concentration in the winter in 2012

Relatively small size diatoms appear at western side of Ariake bay area in the middle of February and then large size diatoms appear in the whole area of Ariake bay area from 25 February to the middle of April 2012. The influencing factors, meteorological condition, turbidity, chlorophyll-a, river water flow, tidal height is collected from the Japanese Meteorological Agency: JMA, MODIS data and diatom 
appearance. These data of 2012 are plotted in Fig.3 (a). In the figure, Eucampia zodiacus (top) and Skeletonema spp. (bottom) appearances which are reported by the Ito et al. [1] are also plotted in the top right corner of the figure. These are time series of the depth distributions of diatom for the period

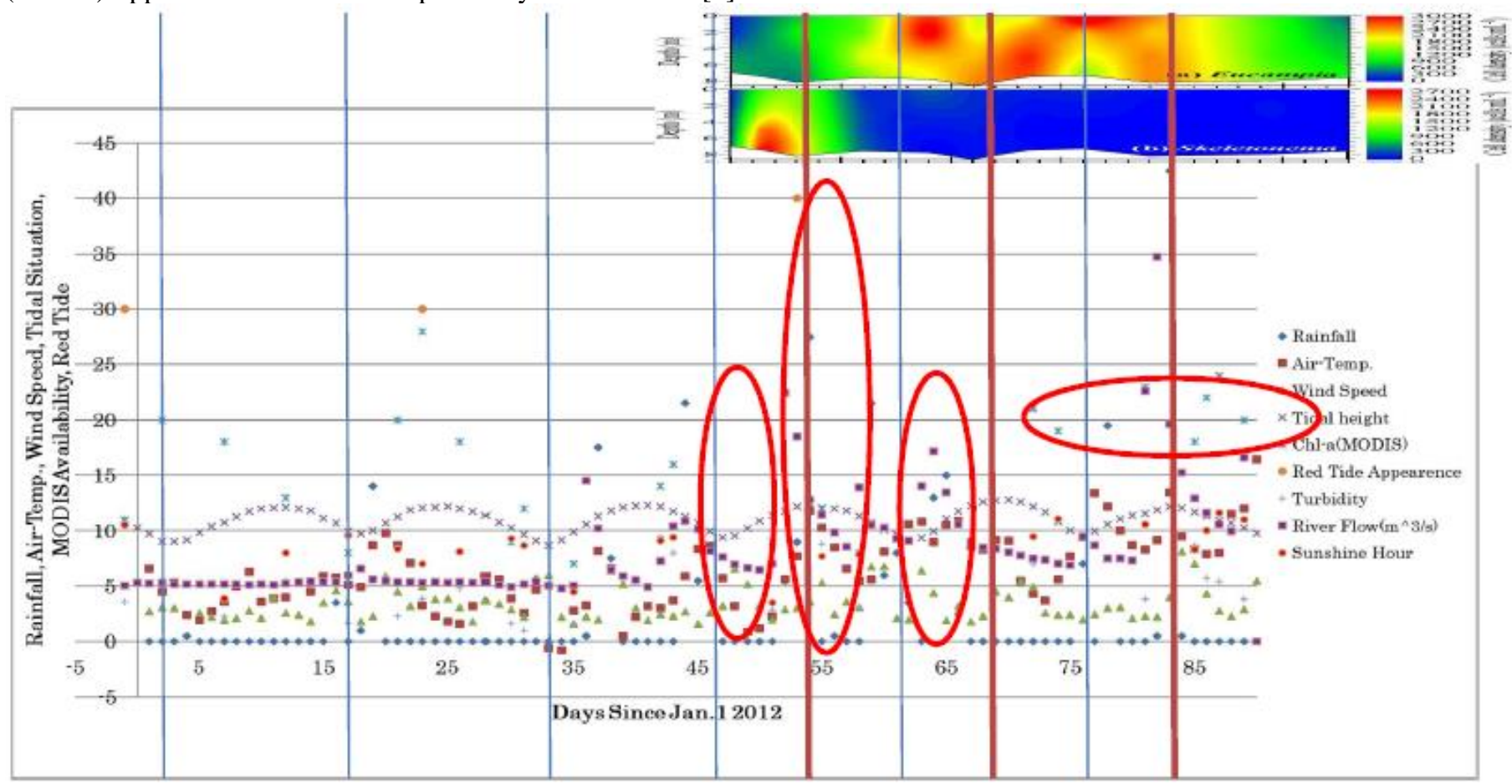

(a) 2012

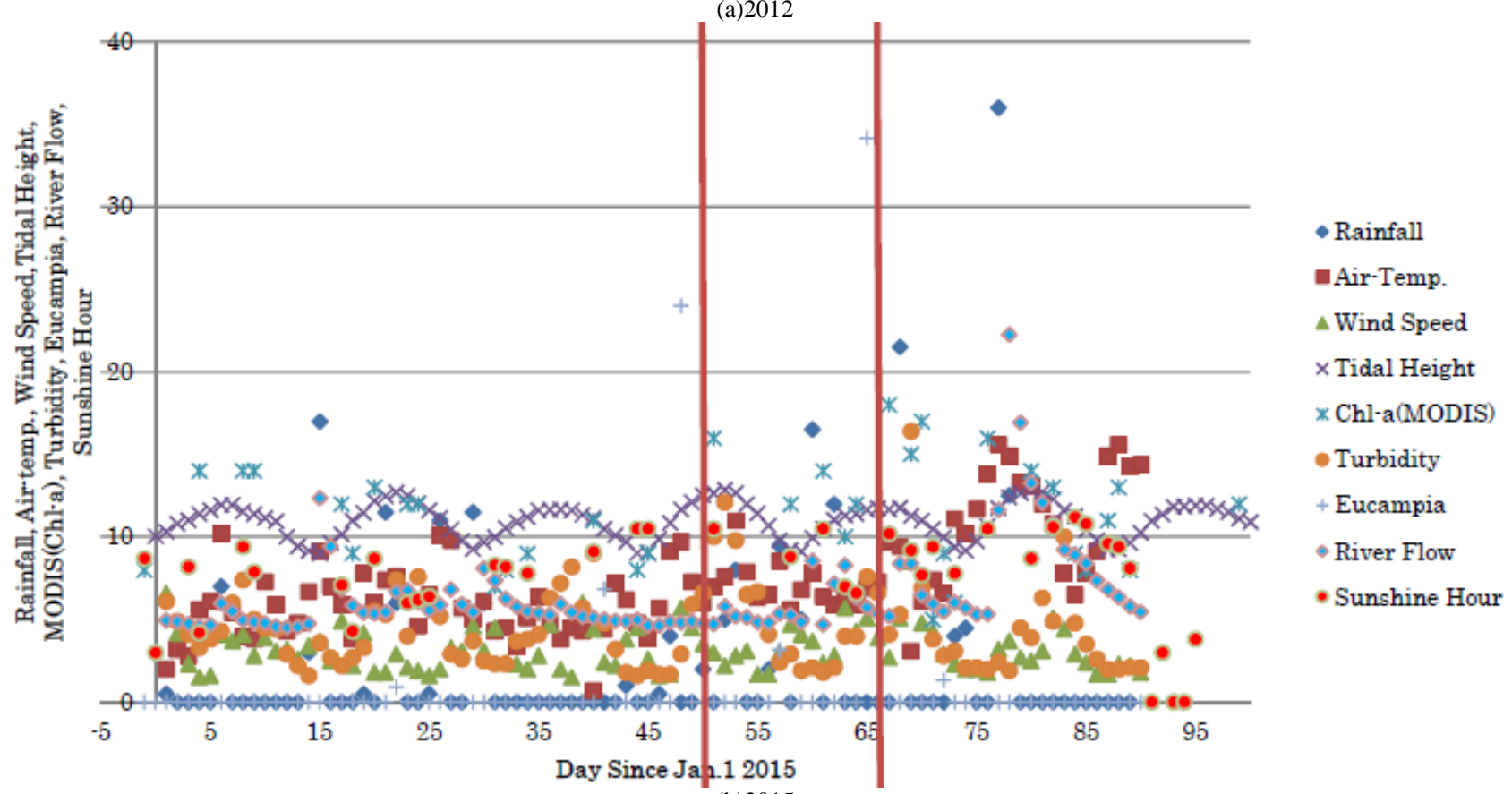

(b) 2015

Fig. 3. Measured meteorological data and tidal height as well as river flow data together with MODIS derived turbidity and chlorophyll-a data

Fig.3 (b) shows the influencing factors and diatom appearance in 2015. The MODIS clear scenes of data acquisition dates for the period from the late of December 2014 to the end of April 2015 are followings,

(1) $2014 / 12 / 26,30$

(2) $2015 / 1 / 7,8,17,18,20,24,31$
(3) $2015 / 2 / 1,3,9,13,14,27$

(4) $2015 / 3 / 2,4,8,11,12,14,17,21,23,25,26,28,29,30$

(5) $2015 / 4 / 15,17,21,23,25,26$

As a matter of fact, diatom needs nutrients, sunshine, appropriate sea temperature (22 to 26 degree Celsius) and salinity (15 to $28 \%$ ), as well as diatom seeds. Nutrients are 
provided by river water (source of nutrients) which is mainly caused by rainfall and run-off water. Therefore, river water flow is a key component for nutrients. Relatively large diatom (Eucampia zodiacus) seeds are situated in the bottom layer situated in Ariake bay while relatively small diatom seeds are situated from the sensory ranges of the specific rivers, ShiotaRiver for Skeletonema spp. and Asteroplanus karianus. Therefore, convection or vertical mixing in the sea water of Arirake bay is a key for the large diatom appearance at the sea surface. The convection is usually occurred due to spring tide or strong winds from the north. Therefore, diatom bloom is used to be occurred in spring tide. Also, diatom seeds need sunshine, nutrients for blooming. Therefore, diatom bloom occurs after a relatively large river water flow followed by relatively small turbidity and sunshine as well as spring tide. These are mechanism for diatom appearance and bloom.

\section{MODIS Data Derived Turbidity in Particular in 2015}

As is mentioned before, method for estimation of turbidity with MODIS data is still under discussion. To create a method for turbidity estimation, a regressive analysis is conducted with MODIS 547nm band data and in-situ data of the measured turbidity at the Saga University Tower. Fig.4 shows examples of MODIS imagery data (False color representation) acquired on (a) January 17, (b) February 14 and (c) March 30 in 2015. In these figures, histogram of the white square sea area (Saga University Tower is situated) of MODIS $547 \mathrm{~nm}$ band data (colored in blue) is shown. 29 of in-situ data of turbidity are used for the regressive analysis. The result is shown in Fig.5.

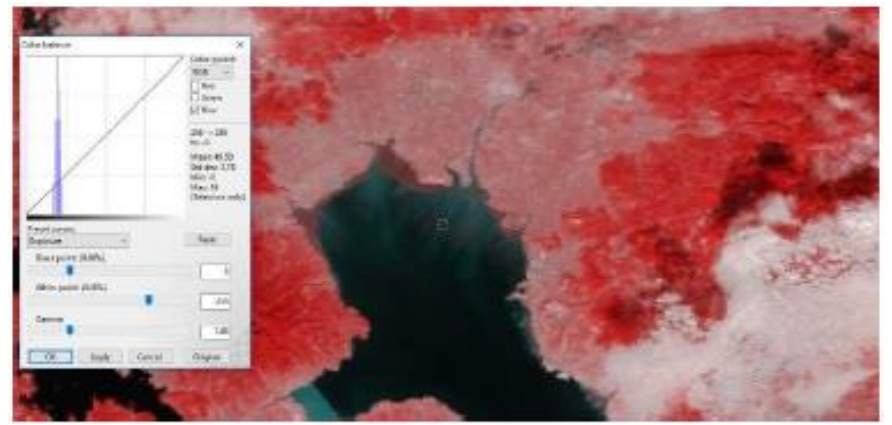

(a)January 17

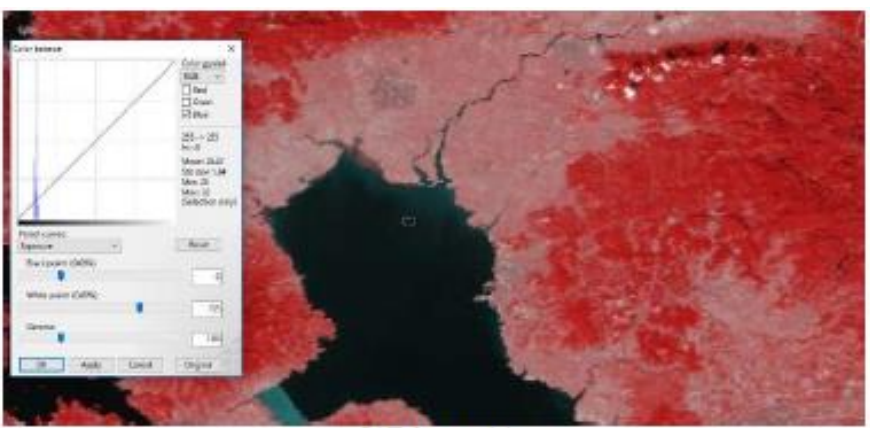

(b)February14

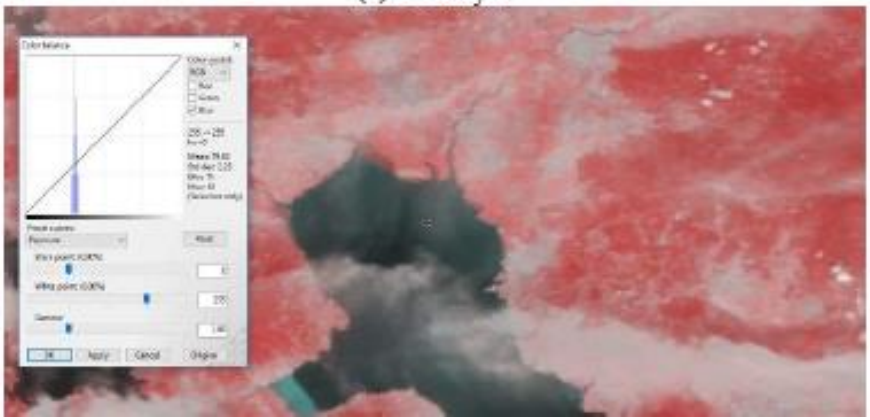

(c)March30

Fig. 4. False color representation of MODIS imagery which includes MODIS 547nm band data as blue color component in the false color component

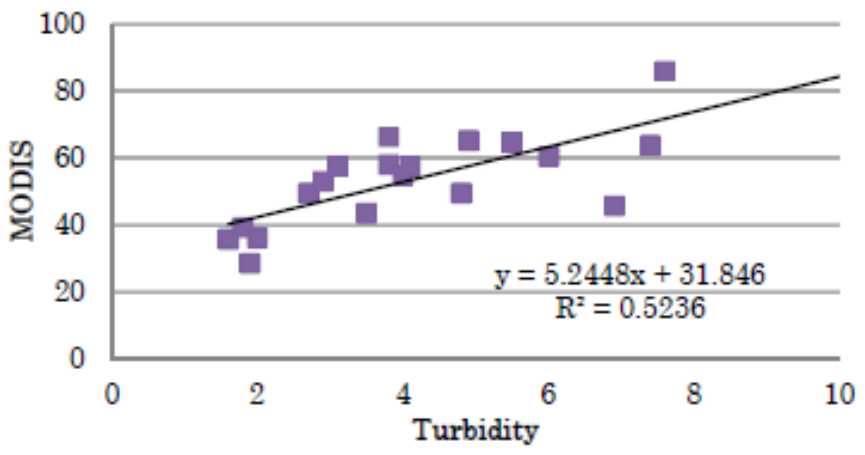

Fig. 5. Relation between in-situ data of turbidity measured at the Saga University observation tower and the estimated turbidity derived from MODIS $547 \mathrm{~nm}$ band of data 
As the result, it is found that the turbidity can be estimated with the following regressive equation,

Turbidity $=5.2448$ MODIS $_{547 \mathrm{~nm}}+31.846$

In the regressive analysis, it is confirmed that $\mathrm{R}^{2}=0.5236$ or 0.7236 of correlation coefficient.

\section{Warning or Caution for Diatom Appearance}

Warning or caution of diatom appearance can be provided to fishermen (Nori farmers) in accordance with the following scenario,

1) Check river water inflow during tidal wave

2) If the river water inflow is greater than the previously set threshold, then check the MODIS derived turbidity and the sunshine hour as well as the MODIS derived chlorophyll-a concentration

3) If not, then go back to the process (1)

4) And if the MODIS derived turbidity is less than the previously set threshold and sunshine hour and the MODIS derived chlorophyll-a concentration is greater than the previously set threshold, then warning or caution is provided for the next sprig tide

5) If not, then go back to the process (1).

\section{E. Spatial Distribution of Diatom Appearance}

Spatial distribution of diatom appearance can be estimated with turbidity distribution in the tidal wave and chlorophyll-a concentration distribution after the tidal wave. Fig.6 shows an example of the MODIS derived turbidity distribution in the tidal wave and the MODIS derived chlorophyll-a concentration distribution just after the tidal wave. The areas of which the turbidity is less than the threshold and the chlorophyll-a concentration is greater than the threshold is determined as warning areas of diatom appearance.
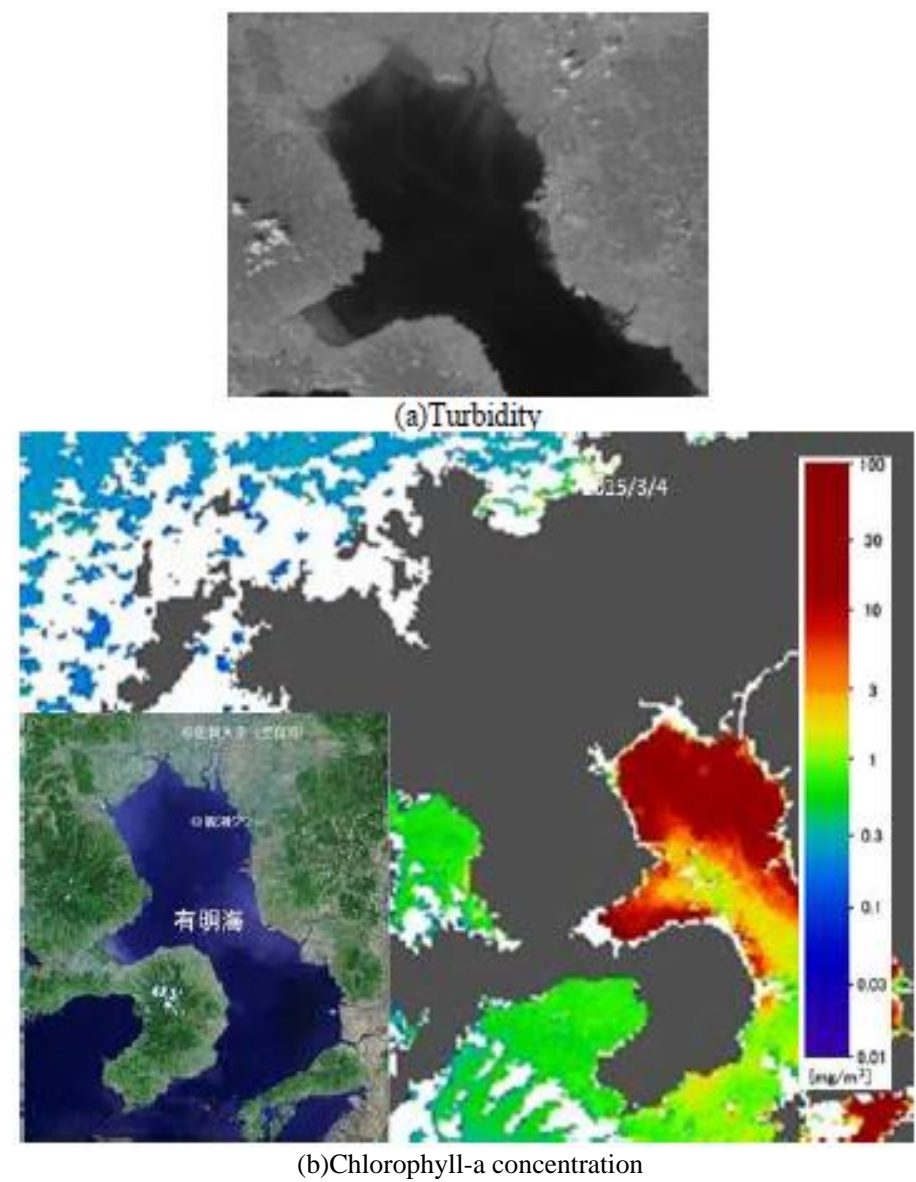

Fig. 6. Example of the MODIS derived turbidity distribution in the tidal wave and the MODIS derived chlorophyll-a concentration distribution just after the tidal wave 


\section{CONCLUSION}

Prediction method for large diatom appearance in winter with meteorological data and MODIS derived turbidity and chlorophyll-a in Ariake Bay Area in Japan is proposed. Because the proposed large diatom prediction method is totally new, there is no comparison between the proposed method and the other method at all. Mechanism for large diatom appearance in winter is discussed with the influencing factors, meteorological condition and in-situ data of turbidity, chlorophyll-a data with the measuring instruments equipped at the Saga University own Tower in the Ariake Bay area. The discussed mechanism here is almost same as the previous discussions [1]-[12]. The method for estimation of turbidity is proposed here. Estimation accuracy of turbidity with MODIS data depends on ocean areas, seasons, etc. 0.7236 of the correlation coefficient of the regression analysis is not so bad in comparison to the other trials (around 0.7 of correlation coefficients).

Through experiments, it is found that the proposed prediction method for large diatom appearance is validated with the meteorological data and MODIS derived turbidity and chlorophyll-a data estimated for the winter (from January to March) in 2012 and 2015.

Further investigations are required for confirmation of the mechanism of relatively large diatom appearance with not only 2012 and 2015 but also other years, 2010, 2011, 2013, 2014, and 2016 as well as 2017. Also, it is required to clarify the mechanism of relatively small size diatom appearance.

\section{ACKNOWLEDGMENT}

The author would like to thank Dr. Toshiya Katano of Tokyo University of Marine Science and Technology, Dr. Joji Ishizaka of Nagoya University, Dr. Minoru Wada of Nagasaki University, Dr. Yuichi Hayami, Dr. Kei Kimura, Dr. Kenji Yoshino, Dr. Naoki Fujii of Institute of Lowland and Marine Research, Saga University and Dr. Takaharu Hamada of the University of Tokyo for their great supports through the experiments.

\section{REFERENCES}

[1] Ito Y., Katano T., Fujii N., Koriyama M., Yoshino K., Hayami Y., Decreases in turbidity during neap tides initiate late winter large diatom blooms in a macrotidal embayment, Journal of Oceanography,69: 467479. 2013.

[2] Nishikawa $T$, Effects of temperature, salinity and irradiance on the growth of the diatom Eucampia zodiacus caused bleaching seaweed Porphyra isolated from Harima-Nada, Seto Inland Sea, Japan. Nippon Suisan Gakk 68: 356-361. (in Japanese with English abstract), 2002.

[3] Nishikawa $T$, Occurrence of diatom blooms and damage tocultured Porphyra thalli by bleaching. Aquabiology 172: 405-410. (in Japanese with English abstract), 2007.

[4] Nishikawa T, Hori Y., Effects of nitrogen, phosphorus and silicon on the growth of the diatom Eucampia zodiacus caused bleaching of seaweed Porphyra isolated from Harima-Nada, Seto Inland Sea, Japan. Nippon Suisan Gakk 70: 31-38. (in Japanese with English abstract), 2004.

[5] Nishikawa T, Hori Y, Nagai S, Miyahara K, Nakamura Y, Harada K, Tanda M, Manabe T, Tada K, Nutrient and phytoplankton dynamics in Harima-Nada, eastern Seto Inland Sea, Japan during a 35- year period from 1973 to 2007. Estuaries Coasts 33: 417-427, 2010.

[6] Nishikawa T, Hori Y, Tanida K, Imai I, Population dynamics of the harmful diatom Eucampia zodiacus Ehrenberg causing bleachings of
Porphyra thalli in aquaculture in Harima- Nada, the Seto Inland Sea, Japan. Harmful algae 6: 763-773, 2007.

[7] Nishikawa T, Miyahara K, Nagai S., Effects of temperature and salinity on the growth of the giant diatom Coscinodiscus wailesii isolated from Harima-Nada, Seto Inland Sea, Japan. Nippon Suisan Gakk 66: 993-998. (in Japanese with English abstract), 2000.

[8] Nishikawa T, Tarutani K, Yamamoto T., Nitrate and phosphate uptake kinetics of the harmful diatom Eucampia zodiacus Ehrenberg, a causative organism in the bleaching of aquacultured Porphyra thalii. Harmful algae 8: 513-517, 2009.

[9] Nishikawa T, Yamaguchi M., Effect of temperature on lightlimited growth of the harmful diatom Eucampia zodiacus Ehrenberg, a causative organism in the discoloration of Porphyra thalli. Harmful Algae 5: 141147, 2006.

[10] Nishikawa T, Yamaguchi M., Effect of temperature on lightlimited growth of the harmful diatom Coscinodiscus wailesii, a causative organism in the bleaching of aquacultured Porphyra thalli. Harmful Algae 7: 561-566, 2008.

[11] Syutou T, Matsubara T, Kuno K., Nutrient state and nori aquaculture in Ariake Bay. Aquabiology 181: 168-170. (in Japanese with English abstract), 2009.

[12] Harada K, Hori Y, Nishikawa T, Fujiwara T., Relationship between cultured Porphyra and nutrients in Harima-Nada, eastern part of the Seto Inland Sea. Aquabiology 181: 146-149. (in Japanese with English abstract), 2009.

[13] Arai K., T. Katano, Trend analysis of relatively large diatoms which appear in the intensive study area of the ARIAKE Sea, Japan, in winter (2011-2015) based on remote sensing satellite data, Internationa Journal of Advanced Research in Artificial Intelligence (IJARAI), 4, 7, 15-20, 2015.

[14] Arai, K., Locality of Chlorophyll-a Concentration in the Intensive Study Area of the Ariake Sea, Japan in Winter Seasons Based on Remote Sensing Satellite Data, Internationa Journal of Advanced Research in Artificial Intelligence (IJARAI), 4, 8, 18-25, 2015.

[15] Kohei Arai, One of the Possible Causes for Diatom Appearance in Ariake Bay Area in Japan in the Winter from 2010 to 2015 (Clarified with AQUA/MODIS), International Journal of Advanced Research on Artificial Intelligence, 5, 4, 1-8, 2016.

[16] Kohei Arai, Relation between Large Sized Diatom Appearance and Meteorological Data in Ariake Bay Area in Japan, in Particular, in the Winter in 2016, International Journal of Engineering Science and Research Technology, 2, 2, 1-9, 2016

[17] Ng H.G., Matja fri M.Z., Abdullah K., Alias A.N., Comparison of turbidity measurements by MOIS and AVHRR images, Proceeding of the CGIV '08 Proceedings of the 2008 Fifth International Conference on Computer Graphics, Imaging and Visualisation, 398-403, 2008.

\section{AUTHORS PROFILE}

Kohei Arai, He received BS, MS and PhD degrees in 1972, 1974 and 1982, respectively. He was with The Institute for Industrial Science and Technology of the University of Tokyo from April 1974 to December 1978 also was with National Space Development Agency of Japan from January, 1979 to March, 1990. During from 1985 to 1987, he was with Canada Centre for Remote Sensing as a Post Doctoral Fellow of National Science and Engineering Research Council of Canada. He moved to Saga University as a Professor in Department of Information Science on April 1990. He was a councilor for the Aeronautics and Space related to the Technology Committee of the Ministry of Science and Technology during from 1998 to 2000. He was a councilor of Saga University for 2002 and 2003. He also was an executive councilor for the Remote Sensing Society of Japan for 2003 to 2005. He is an Adjunct Professor of University of Arizona, USA since 1998. He also is Vice Chairman of the Commission "A" of ICSU/COSPAR for 8 years, 2008-2016 then he is now award committee member of ICSU/COSPAR. He wrote 37 books and published 570 journal papers. He received 30 of awards including ICSU/COSPAR Vikram Sarabhai Medal in 2016, and Science award of Ministry of Mister of Education of Japan in 2015. He is now Editor-in-Chief of IJACSA and IJISA. http://teagis.ip.is.saga-u.ac.jp/index.html 